\title{
GENERA OF PLANCTON ORGANISMS
}

\section{OF THE CAYUGA LAKE BASIN}

\section{QL 143 \\ .364 \\ 1915}

INVZ

ITHACA, N. Y.

Limnological Laboratory of the Department of Entomology in Cornell University 



\section{GENERA OF PLANCTON ORGANISMS OF THE CAYUGA LAKE BASIN}

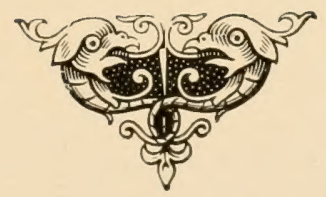

ITHACA, N. Y.

Limnological Laboratory of the Department of Entomology in Cornell University 



\title{
APR 182005
}

\section{GENERA OF PLANCTON ORGANISMS OF THE CAYUGA LAKE BASIN.}

\author{
BY O. A. JOHANNSEN AND J. T. LLOYD.
}

The more advanced student of Limnology will find at his disposal a number of works for the identification of aquatic organisms. These books, however, deal with limited groups, are not readily accessible to the beginning student and not adapted for class work, hence the following keys have been prepared. To make the keys more generally useful some genera are included which have not yet been recorded from this region, but which may be found when our fauna and flora are better known. It will be noted also that a number of forms, especially green algæ, are included which are not truly plancton organisms. The frequency with which they are brought in from the smaller ponds and streams by students, makes this seem advisable.

Except for the general arrangement, no originality is claimed for this work. We are particularly indebted to the writings of Bessey, Birge, Bütschli, Collin, Conn, Eyferth, Herrick, Hudson and Gosse, Jennings, Kent, Stokes, Tilden, Van Douwe, West and Wolle. The figures are in part drawn from the objects themselves, a few from photographs and some from published papers.

\section{ALGÆ.*}

a. Cells blue-green : reproduction by simple division. (See illustration $\mathrm{I}$.) The blue-greens.

(= SCHIZOPHYCE五) CYANOPHYCEA.

b. Cells unicellular or in clusters and colonies: not truly filamentous ; commonly embedded in a gelatinous matrix, more rarely free floating.

COCCOGONEA:

c. Multiplication by vegetative cell division.

CHROOCOCCACE正。

d. Cells solitary, without gelatinous matrix.

e. Cells spherical.

Chroococcus.

ee. Cells elongate. Cylindrical (Synechococcus,- Chroothece) or fusiform

(Dactylococcopsis).

dd. Numerous cells in gelatinous matrix.

e. Colonies and gelatine without definite form.

f. Cells in several gelatinous capsules.

g. Cells spherical, enclosed in shapeless masses of gelatine.

gg. Cells elongate or elliptical.

Glococapsa.

$\mathrm{ff}$. Cells scattered within the gelatinous mass.

g. Cell spherical (fig. 13).

gg. Cell elongate.

Gloeotheca, Zachariasia.

ee. Cells in definite arrangement.

f. Colonies free swimming.

g. Cell division in three planes, colonies therefore in clumps.

h. Cells spherical.

*Adapted from Conn, Engler-Prantl, Fyferth, et al. 
i. Colonies more or less spherical, or formed like a bunch of grapes (figs. 8, 9).

Microcystis.

ii. Colonies spherical when young, torn and net-like when older. Clathrocystis.

hh. Cells wedge shaped; colonies spherical.

Gomphosphara.

gg. Cell division two plane, resulting colonies therefore only one cell deep.

h. Colonies a hollow sphere (fig. IO).

Colospharium.

hh. Colonies sheet like or disc like.

i. Individual cells isodiametric, not flat.

j. Cells spherical, regularly arranged, (fig. 6).

jj. Cells cylindrical, arranged palisade like.

ii. Cells flattened, disc like (fig. 2).

Merismopedia. Holopedium. Tetrapedia.

ff. Colonies attached.

Oncobyrsa.

cc. Multiplication by conidia. Epiphytes on algæ. CHAM ASIPHONACE.

bb. Cells (except Spirulina, fig. I2) filamentous ; branched or unbranched, multiplication by filamentous active hormogones.

HORMOGONEAE.

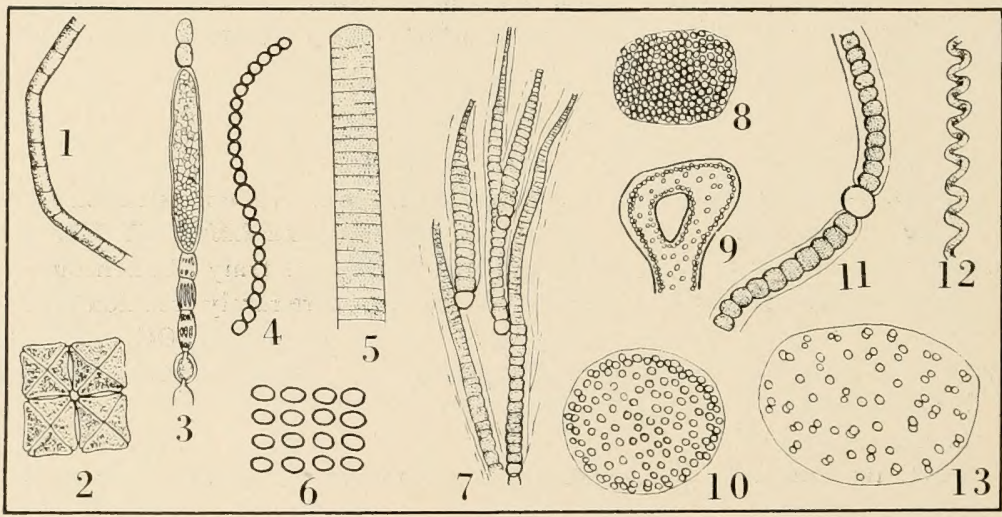

I.-BLUE-Greens. I, Phormidium. 2, Tetrapedia. 3, Aphanizomenon. 4, Anabæna. 5, Oscillatoria. 6, Merismopedia. 7, Rivularia. 8, 9, Microcystis. IO, Coelosphærium. II, Nostoc. I2, Spirulina, I3, Apanocapsa.

c. Filaments not attenuated and hair-like at the ends.

d. Filaments usually not branching; where they show branching there are no heterocysts.

e. Cells of the filament all of uniform size; without heterocysts.

f. Filament without sheath.

Oscillatoriacec.

g. Filament multicellular.

h. Filament not a spiral (fig. 5)

hh. Filament a spiral.

gg. A single spiral cell (fig. I2).

(= Oscillatoria $)$, Oscillaria.

Arthrospira.

ff. Filament enclosed in a gelatinous sheath.

Spirulina. 
g. Only a single filament with one sheath.

h. Sheath thick, slimy, filaments often bent, agglutinated (fig. I). Phormidium.

hh. Sheath firm, not slimy.

i. Filaments not consolidated into bundles.

Lyngbya. Hypheothrix.

ii. Filaments in crest or prostrate bundles.

Symploca.

gg. Usually several filaments in a more or less thick sheath. Several genera.

ee. Filaments with occasional cells of different color or of larger size (heterocysts).

NOSTOCACEA:

f. Filaments contorted, within a definite gelatinous tegument (fig. I I).

Nostoc.

ff. Filament more or less straight, free or in a formless slimy mass, without tegument.

g. Heterocysts not terminal.

h. Filaments aggregated without order (fig. 4).

Anabcena.

hh. Filaments in bundles of plate like masses (fig. 3 ).

gg. Heterocysts terminal ; spores long and cylindrical,

Aphanizomenon.

Cylindrospernum.

dd. Filaments branching.

e. Filaments showing true branching.

STIGONEMACE,

ee. Filaments showing false branching; heterocysts present.

SCYTONEMACE正.

cc. Filaments (trichomes) conspicuously attenuated towards one or both extremities, which are generally hairy.

RIVULARIACE死.

Filaments each with a basal heterocyst; filaments radiating, in a gelatinous mass (fig. 7). Rivularia, Glcotrichia. Several other genera belong to this family.

aa. Cells green, red, or brown.

b. Organism green, not yellowish green; if reddish then unicellular.

c. Organism with whorls of leaves.

CHARACE円. Chara and Nitella.

cc. Organism smaller, without whorls (see illustration II).

CHLOROPHYCE尼.

d. Thallus tubular, multinuclear, cell division not apparent; usually branched.

SIPHONALES. Vaucheria.

dd. Thallus filamentous and septate, or unicellular, or expanded.

e. Thallus expanded, membranous.

ULVALES.

ee. Thallus neither expanded nor membranous.

f. Thallus not filamentous; no conjugation. PROTOCOCCALES.

g. Unicellular, or of a definite number of ciliated motile cells.

Volvocace.

h. Composed of colonies of many cells; cells with 2 cilia.

i. Colonies spherical or circular.

j. No gelatinous cover.

k. Many cells in a hollow globe (fig. 3).

Volvox.

$\mathrm{kk}$. Cells $\mathrm{I} 6$, arranged in four rows.

Spondylomorum. 
jj. With a gelatinous cover.

$\mathrm{k}$. Colony ovate or spherical.

1. Cells 16-32, globose, not crowded (figs. 7, 8) Eudorina.

11. Cells 8, I6, 32, or 64 globose, crowded. (figs. I3, 16).

Pandorina.

$\mathrm{kk}$. Colony of 8 cells in an equatorial zone in a spherical or ellipsoidal investment.

Stephanosphcera.

ii. Colonies flat, cells $4-16$, angles rounded, in a colorless sheath (Compare also Uvella fig. I4). (fig. Io). Gonium.

hh. Composed of single cells with two, or rarely four cilia.

i. Contents of cell close to cell wall (fig. 4).

Chlamydomonas.

ii. Contents of cell connected with cell wall by threads (fig. 2 ).

gg. Cells not ciliated or motile. (See illustration II).

Sphcerella.

$\mathrm{h}$. Cells formed in flat plates or in a net work. HYDRODICTYACE,

i. Cells in a flat plate (fig. I, 2).

ii. Cells form a net work (fig. 25).

Pediastrum.

hh. Cells not in a plate or network.

i. Uniceliular and solitary; cell with differentiation of base and apex (fig. 5).

CHARACIACE, Characium.

ii. Cells without differentiation of base and apex.

j. Unicellular and globular or consisting of short, few celled filaments; firm cell wall. Often in damp situations (figs. 22, 23).

Plérococcace. Pleurococcus.

jj. Not as above.

$\mathrm{k}$. Cells spherical and indefinite in number, embedded in a copious gelatinous envelope (fig. 2I).

PALMELLACE. Tetraspora, et al.

$\mathrm{kk}$. Cells free or colonial, without copious gelatinous envelope ; forming autospores.

PROTOCOCCACEA:

1. Cells elongated, frequently curved; solitary or in definite loosely coherent colonies.

m. Colonies enveloped in mucus (fig. 3).

Kirchneriella. mm. Colonies with little or no mucus.

n. Cells attenuated to acute spines.

o. Cells forming definite colonies each of a single row. ( fig. I4).

Scenodesmus.

oo. Cells solitary or loosely grouped in irregular bundles (figs. II, I2).

Ankistrodesmus.

ooo. Cells lunate, arranged back to back, (fig. 7).

Selenastrum.

nn. Cells sublunate or ellipsoidal, arranged in groups forming irregular colonies.

Dimorphococcus.

11. Cells not elongated.

m. Cells variable, united in a regular flat plate (fig. 26).

mm. Cells not united in a flat plate.

Crucigenia.

n. Cells angular, with a definite number of angles, two, four, six, eight, or more; cells solitary.

Tetraedron. 


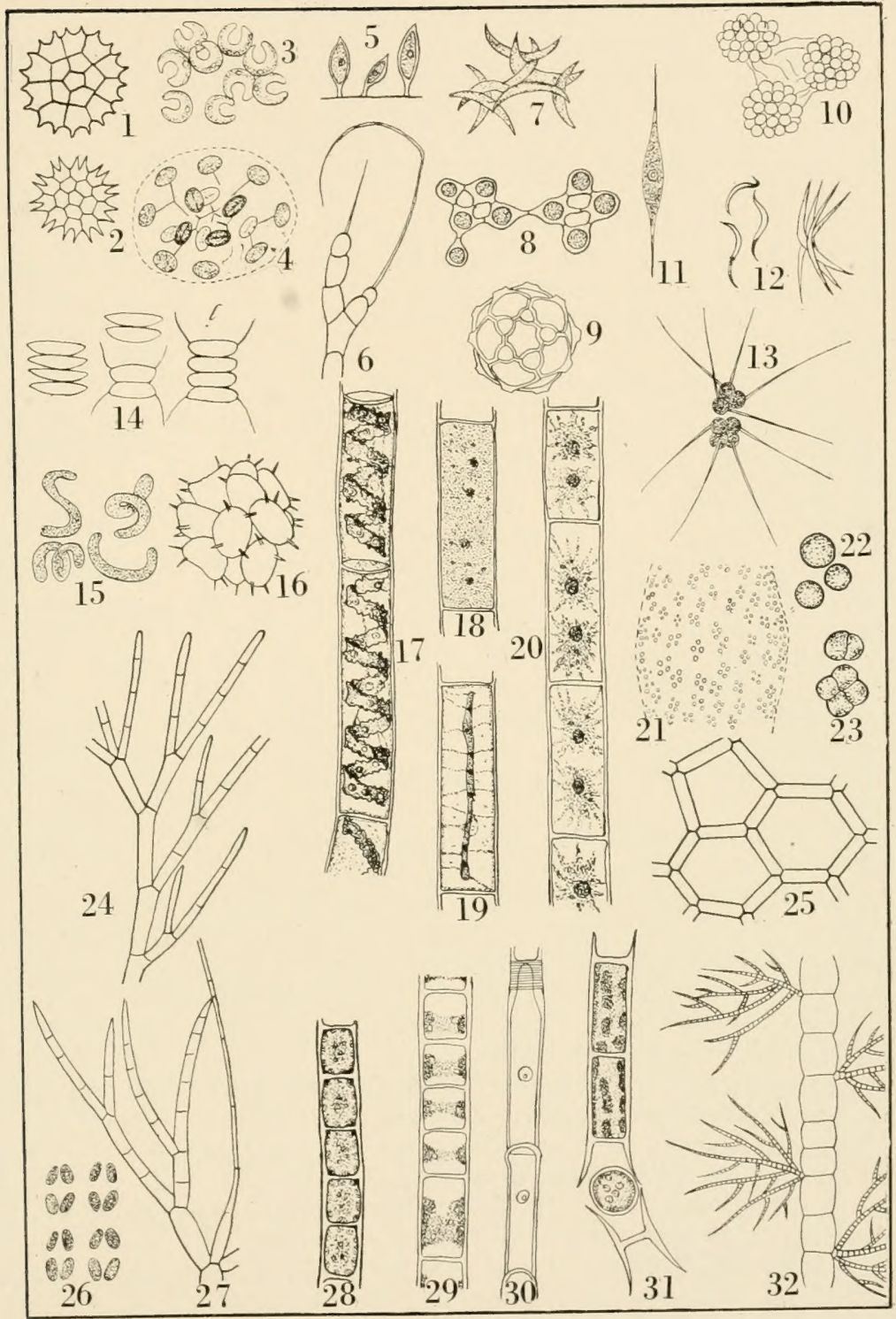

II.-GREEN ALG死. I, 2, Pediastrum. 3, Kirchneriella. 4, Dictyosphærium. 5, Characium. 6, Bulbochæte. 7, Selenastrum. 8, 9, Cœelastrum. Io, Botryococcus. II, 12, Ankistrodesmus. I3, Richteriella. 14, Scenedesmus. 15, Ophiocytium. 16, Sorastrum. I7, Spirogyra. 18, 19, Mougeotia. 20, Zygnema. 21, Tetraspora. 22, 23, Pleurococcus. 24, Cladophora. 25, Hydrodictyon, 26, Crucigenia. 27, Chætophora. 28, Microspora. 29, Ulothrix. 30, Oedogonium. 31, Tribonema. 32, Draparnaldia. 
111. Cells globose or subglobose.

o. Cells strictly globose, united in a spherical colony.

p. Sphere (Cœnobium) hollow (figs. 8, 9) Colastrum.

pp. Sphere solid ( fig. I6).

Sorastrum.

oo. Cells not united in a spherical conobium.

p. Cells with two or more attenuated bristles (fig. I3).

PHYTHELIEA: Richteriella.

pp. Cells without bristles.

q. Cells generally retained within enlarged wall of mother cell.

OÖCYSTIDE王.

qq. Cells joined in colonies by persistent walls of mother cells, which sometimes become transformed into connecting threads.

r. Cells in grape-like clusters, freely exposed in a thin gelatinous envelope (fig. Io) Botryococcus.

rr. Cells indefinitely disposed.

s. With well-marked, subdichotomous connecting threads, chloroplast parietal (fig. 4)

Dictyospharium.

ss. Cells in radiating series, connecting threads scarcely visible; chloroplast axile. Dictyocystis.

ff. Thallus filamentous, though filaments may unite in a plane ; if unicellular then conjugation takes place.

g. Cell division by intercalation of new cells producing transverse striation.

OEDOGONIALES.

h. Cells long, without laterally placed bristles (fig. 30).

hh. Cells short, with laterally placed bristle (fig. 6)

Oedogonium.

gg. Cell division of the ordinary type.

h. Filaments attenuated and commonly ending in a bristle.

CHETOPHORALES.

i. Plant of branched filaments forming a flat cushionlike expansion enveloped in mucilage. COLЕOCHATACE五. Coleocheta.

ii. Plant entirely filamentous, simple.

j. Filaments branched.

k. Gametes arise from special cells only. TRENTEPOHLIACEA. $\mathrm{kk}$. Gametes arise from any cell of the filament.

1. Small creeping filaments upon water plants. m. Cells globose or cylindrical.

HERPOSTEIRACE正: Herposteiron. mm. As above but with flask shaped cell.

CHAETOSPHAERIDIACE王. Chaetosphaeridium.

11. Plants not creeping.

m. Plants less than one mm. high, without setæ.

Microthaminon.

mm. Plants larger, branches attenuated, and with setæ.

n. Filaments fine.

o. Filaments showing little difference in character of stem and branch, not in tufts in gelatinous masses.

Myxonema. 
oo. Filaments in tufts in a dense gelatinous substance (fig. 27).

Chatophora.

n11. Filaments and main branches large, bearing tufts of small branchlets (fig. 32).

jj. Filaments not branched.

Draparnaldia.

$\mathrm{k}$. Cells with thick lamellose coats, in a series inside a lamellose sheath.

CylindRoca PSACExi, Cylindrocapsa.

kk. Cells without lamellose coat.

ULOTHRICHACE ..

1. Filaments attached, chromatophore a homogeneous zonate band, with one to several pyrenoids (fig. 29). Ulothrix.

11. Filaments usually not attached, and chromatophore of a difference character.

in. Chromatophore a parietal disk or plate, with one pyrenoid.

Stichococcus.

mm. Chromatophore granular, covering more or less completely the whole cell wall, containing starch but 110 pyrenoids (fig. 28).

Microsport.

lih. Filaments not ending in a bristle.

i. Chloroplasts numerous, parietal, each with a pyrenoid (fig. 24)

CLADOPHORALES. Cladophora.

ii. Chloroplasts single or several, large and of some definite shape, with pyrenoids. The entire contents of two cells unite to form a single zygote.

CONJUGAT.1:* *

j. Thallus a thread of many similar cells, each zygospore produces only one germ plant.

ZYGNEMACF.E.

k. Chloroplast of spiral bands. (fig. I7). Spirogyra.

$\mathrm{kk}$. Chloraplasts not spiral.

1. Chloroplasts consist of two stellate bodies for each cell (fig. 20).

zygnema.

11. Chloroplast an axile plate. (figs. 18, 19)

Nougeotia.

jj. Unicellular, rarely bound together in a loose thread.

b). Organism yellowish green, red or brown.

DESMIDACE I: (See page 8 ).

c. Organism yellowish green.

HETEROKONTA.

d. Plants unicellular. Chlorobotrys, Ophiocytium (fig. i5).

dd. Plants filamentous, celi wall firm, splitting into $\mathrm{H}$-shaped pieces

(fig. 3!).

Tribonema $(=$ Conferva).

cc. Organism grayish or brownish or amber colored.

d. Unicellular organisms consisting of two silicious valves.

BACILLARIACE王 (= Diatoms) See page Io.

dd. Cells neither silicious nor two valved. (See illustration VI).

PH丑OPHYCE王.

A part of this group is included by the zoologists in the class Mastigophora among the Protozoa. The forms most frequently met with may be distinguished as follows.

e. With two flagella, the smaller lies in a cross furrow, the other in a longitudinal furrow.

* The two orders Schizogoniales and Microsporales are not represented in our plancton. 
f. Membrane of polygonal plates (fig. I8).

Peridinium.

ff. Membrane of plates with long horn-like processes (fig. 17).

Ceratium.

ee. With one or more flagella, no collar, no transverse furrow.

f. With an armor with a pointed posterior end; colonies formed by growth from rim (fig. 5).

Dinobryon.

ff. Colonies of numerous individuals in a gelatinous sphere (fig. 9).

Uroglena.

fff. Spherical colonies of radially arranged individuals each with two brown chromatophores (fig. 15).

Synura.

\section{Desmidiaceae.*}

a. Cell wall apparently not divided into two parts, and without pores.

b. Cells elongate, cylindrical and not constricted, forming loose filaments.

Cell wall with a differentiated outer layer, of which the small roughnesses and spines form a part.

c. Chloroplasts axile (fig. I).

Gonatozygon.

cc. Chloroplasts parietal and spirally twisted (fig. 16). Genicularia.

bb. Cells solitary, relatively short, and mostly unconstricted; cell wall a simple sac, without a differentiated outer layer.

c. One chloroplast in each cell.

d. Chloroplast spirally twisted, axile, or par1etal (fig. 2). Spirotcnia. dd. Chloroplast plane, axile; cells solitary (fig. Io).

Mesolcnium.

cc. Two chloroplasts in each cell.

d. Chloroplasts star-shaped, radiating from a central pyrenoid (fig. 25). Cylindrocystis.

dd. Chloroplasts ridged with longitudinal serrated ridges (fig. I2).

Netrium.

aa. Cell wall showing two segments, and with a differentiated outer porous layer.

b. After division the cells remain free and solitary.

c. Cells not constricted.

d. Cells of moderate length, straight, cylindrical (figs. 17, 23). Penium. dd. Cells elongate, generally curved and attenuated.

e. Cells almost cylindrical, scarcely attenuated; chloroplasts single, without apical moving granules.

Roya.

ee. Cells strongly attenuated towards each extremity ; two chloroplasts in each cell, with apical moving granules (figs. 5, 6, 7, 8).

cc. Cells more or less constricted at the middle.

Closterium.

d. Cells elongated and cylindrical, constriction slight.

e. Apices of cells truncate or round, entire.

f. Base of semi-cells plicate (figs. 3,4 ).

Docidium.

ff. Base of semi-cells plane (fig. 20).

ee. A pices of cells cleft, apical incision narrow (fig. 19). Tetmemorus.

dd. Cells relatively short; deeply constricted.

* Adapted from Conn and Bessey. 


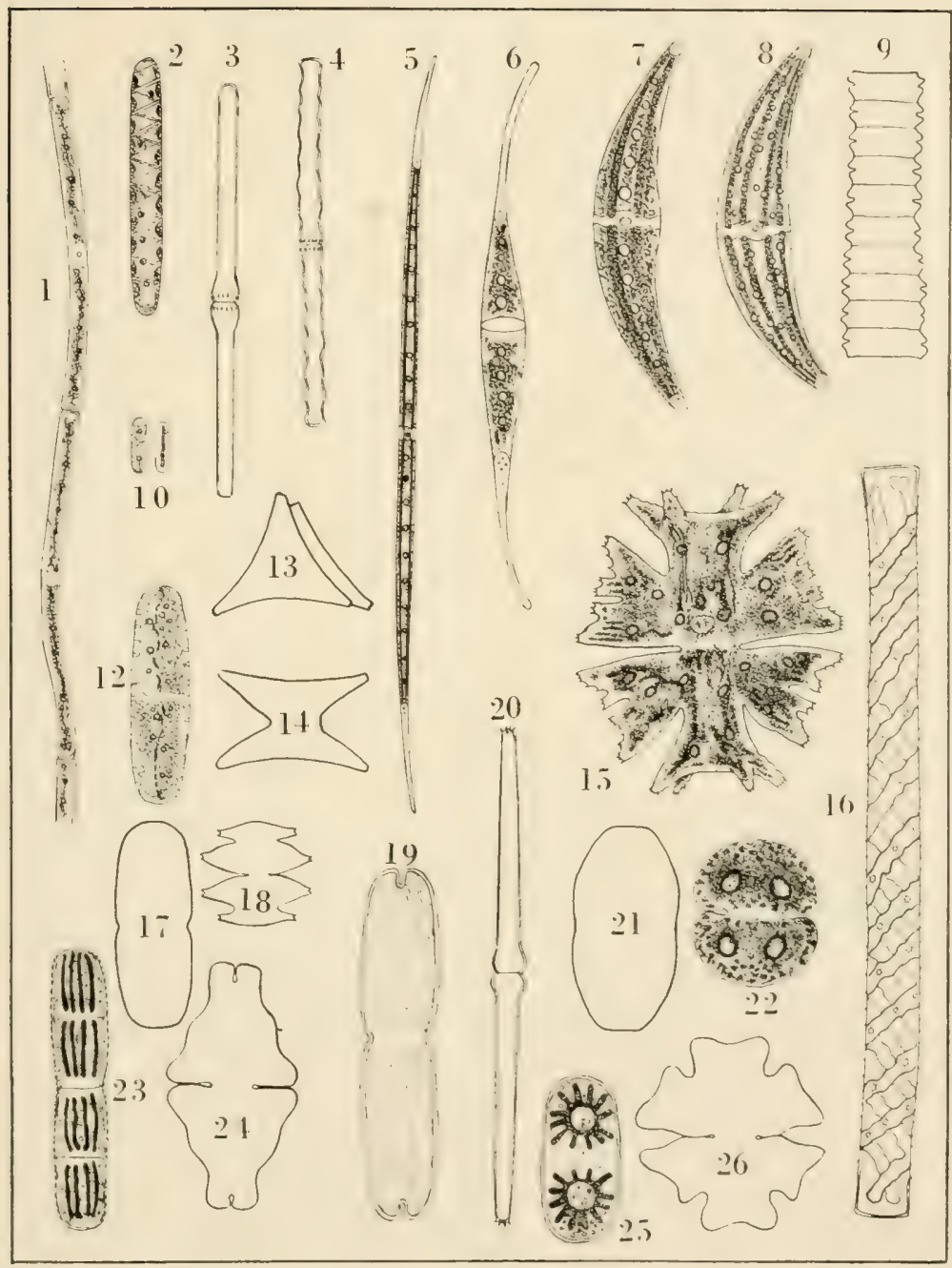

III.-DEsmids. I, Gonatozygon. 2, Spirotania. 3, 4, Docidium. 5, 6, 7, 8, Closterium. 9, Desmidium. IO, Mesotanium. I2, Netrium. 13, Staurastrum (end view 1. I4, Staurastrum (side view). 15. Micrasterias. I6, Genicularia. I7, Penium. IS, Micrasterias. I9, Tetmemorus. 20, Pleurotrenium. 2I, 22, Cosmarimin. 23, Penium. 24, Euastrum, 25, Cylindrocystis. 26, Euastrum. 
e. Cells in vertical view radiating, triangular, quadrangular, or radiate ; rarely fusiform (fig. 13,14 ).

Staurastrum.

ee. Cells compressed (at right angles to the plane of the front view), in the vertical view fusiform or elliptical.

f. Cells lobed or incised.

g. Cells mostly oblong or elliptical; moderately lobed; margins wavy, the depressions rounded (figs, 24, 26).

Euastrum.

gg. Cells very much compressed, mostly orbicular or broadly elliptical, deeply lobed or incised (fig. I5, I8).

Micrasterias.

ff. Cells with a more or less entire margin, often furnished with warts or spines.

g. Cells without spines (figs. 2I, 22).

Cosmarium.

gg. Cell wall with regularly arranged spines of considerable length.

b. Spines several, commonly in pairs; a central protuberance always present.

Xanthidium.

hh. Spines 4 or 8 , occasionally i6, no central protuberance.

Arthrodesmus.

bb. After division the cells remain attached to form colonies.

c. Colonies spheroidal; cells not in contact, but joined by gelatinous bands.

d. Gelatinous bands narrow ; few cells forming a microscopic colony.

Cosmocladium.

dd. Gelatinous bands very broad, many cells forming a microscopic colony.

Oöcardium.

cc. Colonies threadlike; cells attached by their apices to form long filaments.

d. The line of division of the cell where the new and old parts of the cell wall are fitted together, does not develope a girdle during division.

e. Cells attached by special apical processes.

f. Apical processes very short.

Spharozosoma.

ff. Apical processes long and overlapping the apices of the adjoining cells.

Onychonema.

ee. Apices of cells plane and flat.

f. Cells slightly constricted.

Hyalotheca.

ff. Cells deeply constricted; in vertical view elliptical. Spondylosium.

dd. The line of division of the cell, developes a girdle during division.

e. Cells short, in vertical view fusiform, triangular, or quadrangular, rarely circular with produced angles (fig. 9).

Desmidium.

ee. Cells elongate, cylindrical.

Gymnozygas.

\section{Bacillariaceæ (Diatoms.)*}

a. Cells in transection circular, less commonly polygonal or elliptical, and rarely irregular; valves marked concentrically or radiately by dots, areolations, lines or ribs; cells often with spines, processes or horns.

CENTRIC.F.

\footnotetext{
Adapted from Bessey.
} 


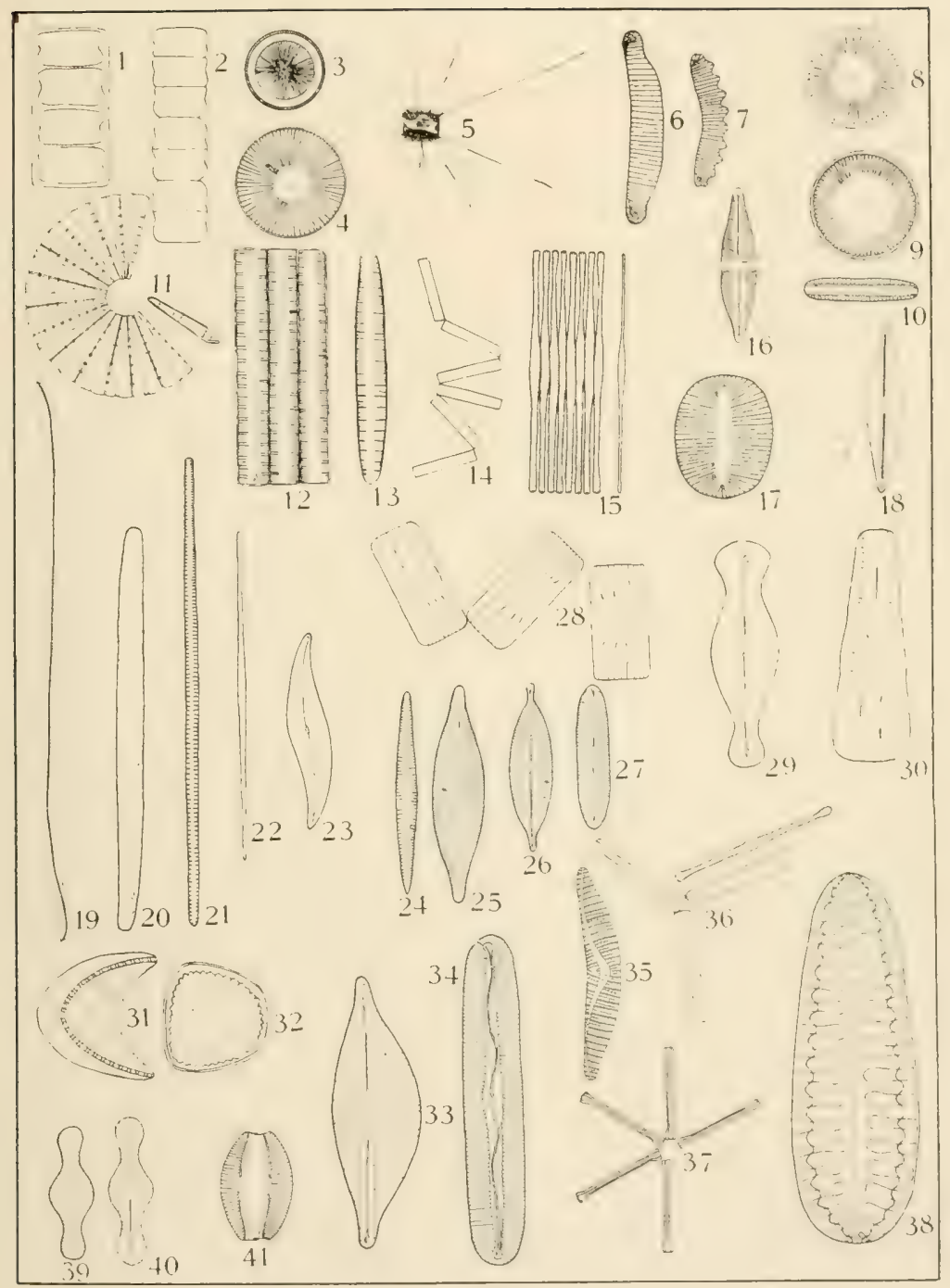

IV.-Dratoms. I, 2, 3, 4, Melosira. 5, Stephanodiscus. 6, 7 , Eunotia. 8, Stephanodiscus. 9, I0, Cyclotella. I I, Meridion. I2, 13, I4, Diatoma. I5, Fragilaria. 16, Stauroaeis. 17, Cocconeis. 18, Frustulia. I9, 20, Nitzchia. 2 I, 22, Synedra. 23, Gyrosigma. 24, 25, 26, 27, Navicula. 28, Tabellaria. 29, 30, Gomphonema. 31, 32, Campylodiscus. 33, Cymbella. 34, Pinnularia. 35, Epithemia. 36, Tabellaria. 37, Asterionella, 38, Surirella. 39, 40, Achnanthidium. 4I, Amphora. 
b. Cells short box-shaped or discoid, mostly circular in transection, usually without horns or projections.

c. Cells forming filaments, girdle side marked.

d. Entire valve uniformly marked (figs. I, 2, 3, 4) (=Lysigonium).

Melosira.

dd. Margin and center of valve differently marked; central portion areolated.

Hyalodictya.

cc. Cells single, girdle side not marked.

d. Without spines (figs. 9, IO).

dd. With circle of spines (figs. 5,8 ).

Cyclotella.

$\mathrm{bb}$. Cells of other forms.

c. Cells two to many times as long as broad, circular, rarely round elliptical in transection; girdle with numerous interzones.

Rhizosolenia.

cc. Cells box shaped, as long as broad or shorter, elliptical, sometimes lunate in transection; valves with horns, valves with transverse septa, without spines.

Terpsine.

aa. Cells in transection narrowly elliptical to linear, less commonly broadly elliptical, lunate cuneate or irregular, valves marked pinnately or transversely by dots, areolations, lines or ribs; cells without spines.

PENNAT.E.

b. Rachis of the valves ( $i . e$. , the line between the divergent pinnate markings) evident as a narrow unmarked strip (pseudoraphe), rarely wanting; valve without slit (raphe, fig. v).

c. Cells usually but little shorter than broad, or longer, with numerous interzones, mostly united into filaments.

d. Transverse rib of the valves, when present, not extending into the cell cavity.

e. Valves with a few prominent transverse ribs.

Tetracylus.

ee. Valves finely transversely striate only; pseudoraphe absent (figs. $28,36)$. (= Striatella) Tabellaria.

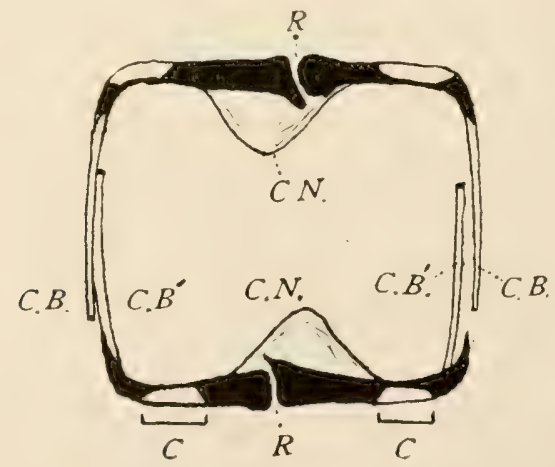

V.- Transverse section of the frustule of a Navicula. (From Van Heurck, after West). cb and $\mathrm{cb}^{\prime}$, the two connectingbands forming the girdle; $r$, raphe; $c n$, central nodule; c, costa of valve. 
dd. Transverse ribs of the valves extending deep into the cell cavity.

Denticula.

cc. Cells prevailingly much shorter than broad (rod-shaped, the longer axis of rod representing transverse axis of cell) often united into filaments.

d. Cells cuneate in girdle view (i.e., valves not parallel) rachis median, interzones present.

e. Valves punctate or variously punctate-striate, without transverse ribs; cells not stalked. Sceptroneis.

ee. Valves finely transverse-striate and with transverse ribs (fig. II).

Meridion.

dd. Cells rectangular in girdle view, or if cuneate the rachis not median, interzones present or absent.

e. Rachis median; without central eye.

f. Valves with transverse ribs; without a central "eye" (figs. I2, I3, I4). $\quad(=$ Odontidium) Diatoma.

ff. Valves without transverse ribs.

g. Ends of valves unequally swollen; cells arranged radially (fig. 37 ).

Asterionella.

gr. Ends of valves alike.

1. Cells in filaments or zig-zag chains; valves flat, without polar nodules ( fig. "I 5 ).

Fragilaria.

hh. Cells single, or forming fan-like stalked clusters. (Figs. 2I, 22).

ee. Rachis near one margin.

f. Ends of valves alike.

g. Pseudoraphe and central nodule evident.

Synedra.

gg. Pseudoraphe and central nodule not evident. (figs. 6, 7)

ff. Ends of valves unlike

(=Actinella) Tibiella.

bb. Rachis otherwise; raphe (slit) present.

c. Rachis containing an elongate slit (raphe) through the cell wall.

d. Rachis commonly median, often more or less lateral, not keeled or when keeled not punctate, interzones present or absent.

e. Valves parallel.

f. Rachis of valves not keeled.

g. Raphe almost straight.

h. Raphe with a simple border.

i. Septa of interzones (when present) not fenestrate.

j. Cells straight in girdle view. Including the subgenera Stauroneis (fig. 16), Frustulia (fig. I8) and Pinnularia (fig. 34).

(Figs. 24, 25, 26, 27).

Navicula.

jj. Cells curved.

$\mathrm{k}$. Both valves with a raphe.

Rhoiconeis.

kk. Only one valve with a raphe. Achnanthes (including Achnanthidium figs. 39,40 ).

ii. Septa of interzones fenestrated.

j. Both valves with a raphe.

jj. Only one valve with a raphe (fig. I7).

Mastogloia.

Cocconeis. 
h11. Raphe bordered by two ridges.

i. Central nodule small or only slightly elongated. Brebissonia.

ii. Central nodule much elongated, rib like. Amphipleura.

gg. Raphe strongly sigmoid.

1. Cell not twisted (fig. 23).

Gyrosigma.

hl. Cell twisted.

Scoliopleura.

ff. Rachis of valve with a keel; keel (including raphe) sigmoid, median.

Amphiprora.

ee. Valves not parallel.

f. Ends of valves approximating.

g. Cells straight in girdle view (figs. 29, 30).

gg. Cells curved in girdle view.

Gomphonema.

ff. Edges of valves approximating.

g. Valves without transverse ribs.

l. Girdle narrow, not striate (fig. 33).

hh. Girdle broad, striate (fig. 4r).

Cymbella.

gr. Valves with transverse ribs, raphe not evident. (fig. 35).

(Cystopleura) Epithemia.

dd. Rachis lateral, less often median, punctate keeled, raphe not plainly visible.

e. Keel median.

Bacillaria.

ee. Keel at one edge (figs. 19, 20). (=Homoeocladia) Nitzchia.

cc. Rachis evident as a narrow, unmarked strip or keeled; valve with two lateral wing keels, each enclosing a raphe.

d. Valve surface undulate. (=Cymatopleura) Sphinctocystis. dd. Valve surface not undulate.

e. Valve cuneate, reniform, elliptical or linear (fig. 38). Surivella.

ee. Valves sub circular, saddle shaped (figs. 3r, 32). Campylodiscus.

\section{PROTOZOA.}

a. Animals with tentacles, and when adult usually attached by a stalk.

SUCTORIA.

aa. Animals with pseudopods, flagella, or cilia.

b. Animals with pseudopodia.

c. Pseudopods flexible. Amceba (fig. 5), Arcella (figs. 3, 4), Difflugia (fig. 6).

RHIZOPODA.

cc. Pseudopods rigid.

HELIOZOA.

bb. Animals with cilia or flagella.

c. Animals with cilia. Paramœecium, etc.

CILIATA.

cc. Animals with $\mathbf{I}$ or 2, rarely more, long flagella, MASTIGOPHORA.

To the Mastigophora belongs a large number of forms, many of which

by botanists are grouped with Algre. The green colonial forms, Volvox, Eudorina, Pandorina, Slephanosphera, Gonium, Chlamydomonas, Spharella, and the brown or colorless genera Peridinium, Ceratium, Dinobryon, Ur.glena, and Synura have already been included in the foregoing keys. Among the numerous forms which may be encountered, are Carteria (fig. I) with four flagella; Mallomonas (fig. 12) with amber colored chromato- 


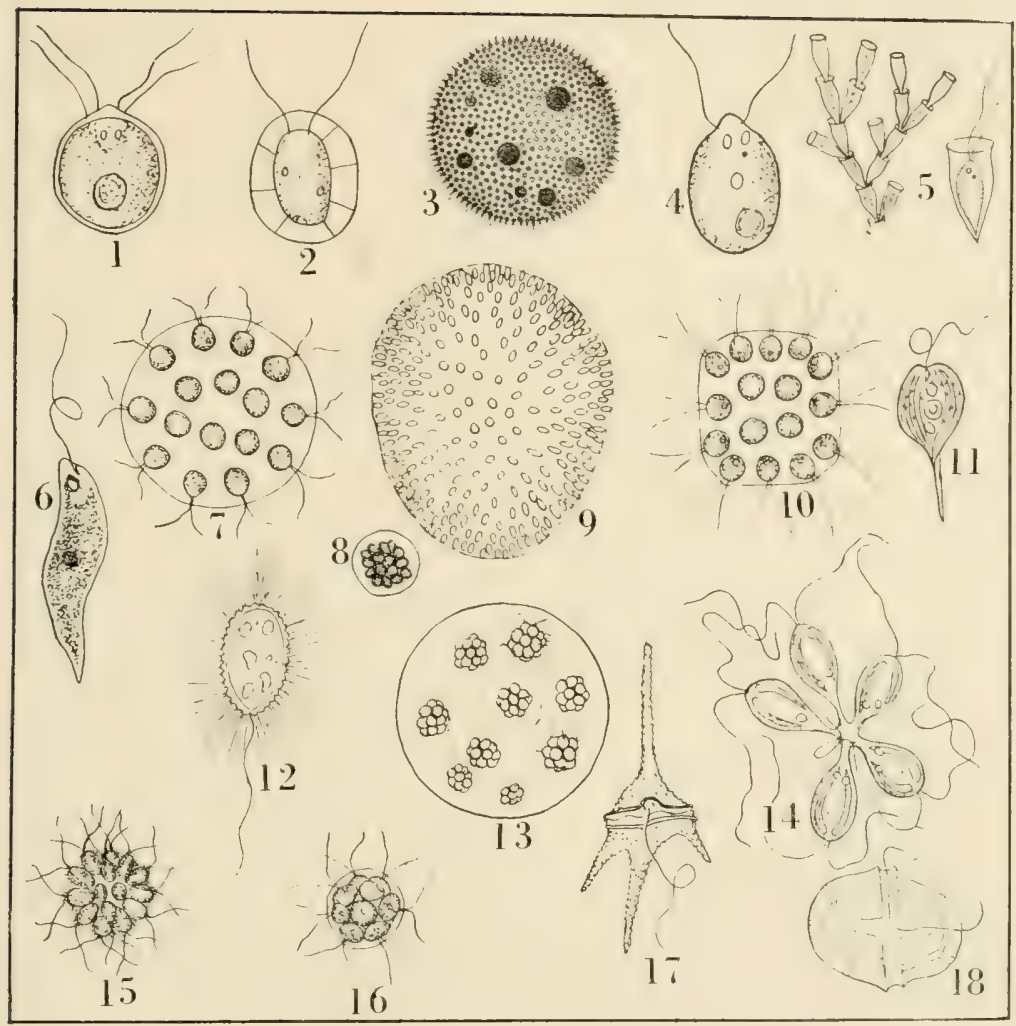

VI.-Finageliates. I, Carteria. 2, Sphrerella. 3, Volvox. 4, Chlamydomonas. 5, Dinobryon. 6, Euglena. 7, Eudorina. 8, Eudorina (young colony). 9, Uroglena. IO, Gonium. II, Phacus. I2, Mallomonas. I3, Pandorina. I4, Uvella. I5, Synura. I6, Pandorina. I7, Ceratium. IS, Peridinium.

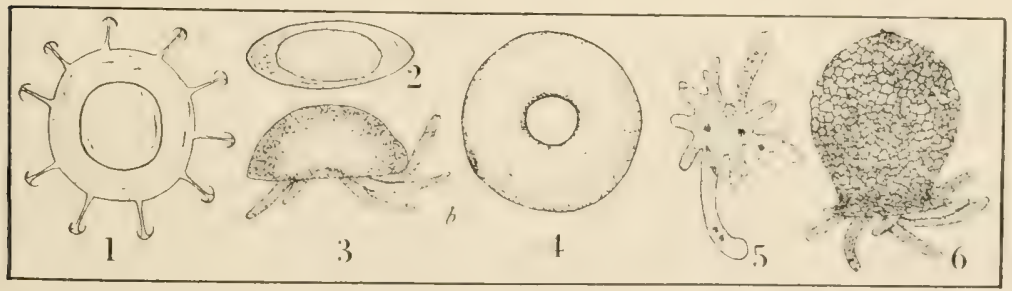

VII.-I, Statoblast of Plumatella. 2, Statoblast'of Pectinatella. 3, Arcella, lateral view. 4, Arcella, ventral view. 5, Amcba. 6, Difflugia. 
phores, and a shell of over lapping plates bearing long spines; Euglena (fig. 6) and Phacus (fig. II), both green in color and with red eye, the former with flexible body, the latter rigid.

\section{ROTIFERA.*}

a. Jaws ramate (fig. Io), lateral palpi wanting; not fixed when adult, not forming colonies, rarely living in tubes; body ringed transversely; head and foot telescopic retractile; no armor; swimming with the corona and creeping like a leech by the help of proboscis and foot; a proboscis, sometimes small, behind the corona. Two ovaries.

DIGONONTA. BDELLOIDEA.

b. Corona of two circular retractile lobes.

PHILODINIDË.

c. Eyes present.

d. Eyes in the neck, just above the jaws (fig. I).

Philodina.

dd. Eyes on the proboscis (figs. 2, 3).

cc. Eyes absent.

Rotifer.

bb. Corona a flat ventral ciliated disk. (fig. 4) ADINETID f - Adineta.

aa. Jaws never ramate, lateral palpi always present, though sometimes indistinct, head and foot not telescopic retractile; movement not leech-like nor inch-worm like; not fixed, no dorsal proboscis behind the corona. One ovary.

MONOGONONTA.

b. Adult animals attached or united in colonies, usually dwelling in tubes, or if separate and free swimming then carrying the transparent tube with them; foot ending in a flat disk or cup, which is attached to the substratum or to the bottom of the tube (or foot absent) ; free swimming when young.

RHIZO'A.

c. Corona with long setæ or conspicuous moving cilia, or both.

d. Corona with long slender setæ and usually produced into a varying number of tubes bearing the setæ; mouth in the center of the large corona; cilia few, about the mouth scarcely noticeable; jaws uncinate; not forming colonies.

FLOSCULARID王:

e. Setre not arranged in whorls or parallel rows on the lobes of the corona, but scattered, or in groups (fig. 5). Floscularia.

ee. Setæ arranged in whorls or oblique parallel rows on the 5 long pointed lobes of the corona (fig. 6). Stephanoceros.

dd. Corona without setre and not produced into long lobes, but with strong conspicuous moving cilia forming a marginal continuous curve on the dorsal side; mouth near the ventral side of the corona; on the body just below the corona either a single dorsal antenna or two ventral ones or all three are noticeable; jaws malleo-ramate (fig. II). MELICERTID无。

e. In clusters of usually many individuals, frequently forming a spherical colony.

f. Clusters attached.

g. Body with 2 or 4 opaque warts in a transverse row on the ventral side; no tube; corona broad, kidney shaped; with short axis dorso-ventral, antennæ inconspicuous.

Megalotrocha.

* Adapted from keys given by Jennings, Collin, et al. 


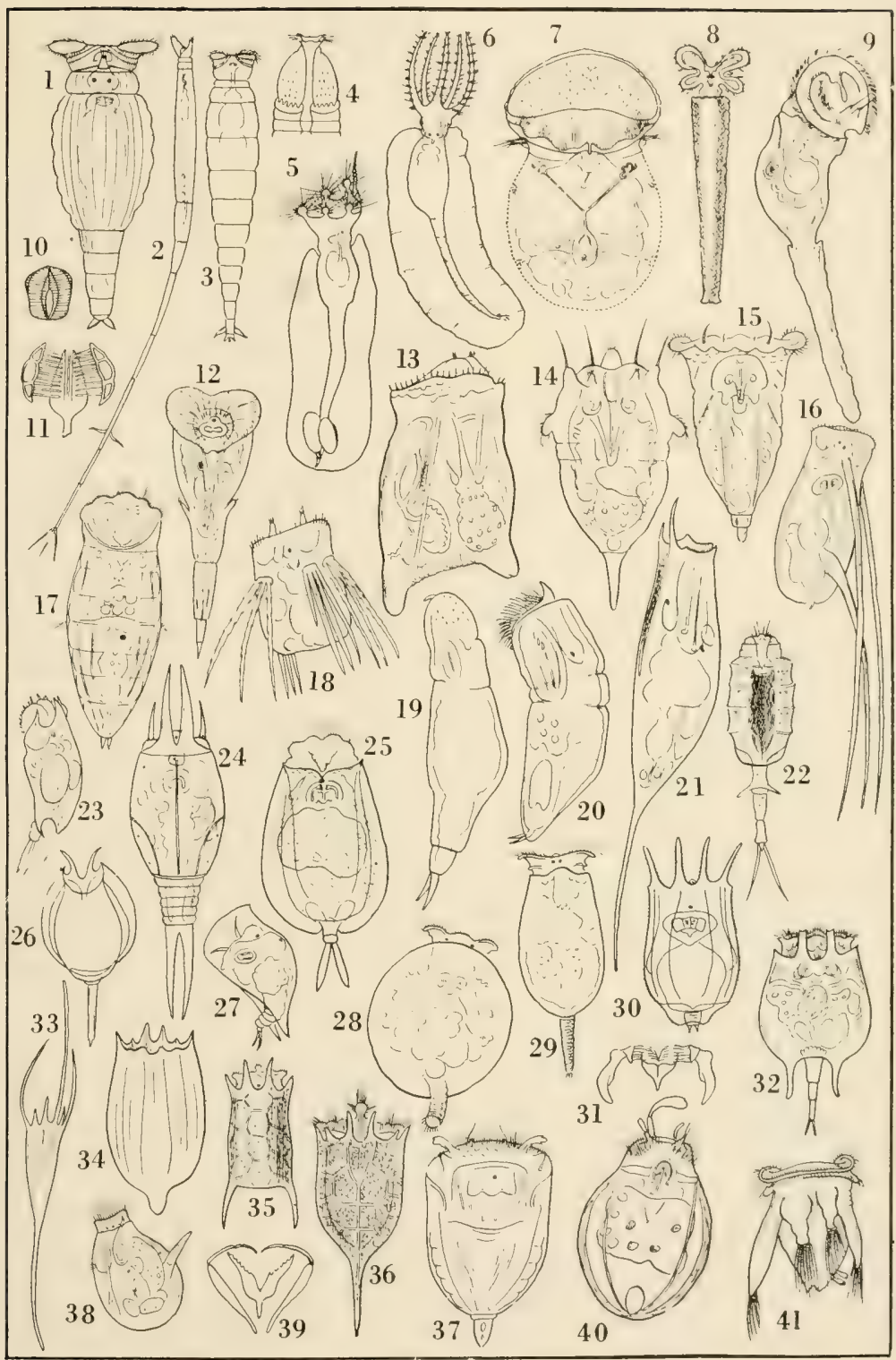

VIII.-RotiFERA, I. Philodina. 2, 3, Rotifer. 4, Adineta, 5, Filoscularia. 6, Stephanoceros. 7, Apsilus. S, Melicerta. 9, Conochilus. Io, Ramate jaws. I1, Malleo-ramate jaws. 12, Microcodon. 13, Asplanchna. I4, 15, Syncheta. I6, Triarthra. I7, Hydatina. IS, Polyarthra. 19, Diglena. 20, Diurella. 2I, Rattulus. 22, Dinocharis. 23, 24, Salpina. 25, Euchlanis. 26, Monostyla. 27. Colurus. 28, 29, Pterodina. 30, Brachionus, 3r, Malleate jaws. 32 , Noteus. 33, 34, Notholca. 35, 36, Anuraea. 37 , Plnesoma. 38 , Gastropus. 39, Forcipate jaws. 40, Anapus. 4I, Pedalion. 
gg. Dwelling in a transparent tube; body without opaque warts or denticles; corona heart-shaped and long axis dorso-ventral; antennæ inconspicuous.

ff. Free swimming colonies or clusters (fig. 9).

Lacinularia.

ee. Individuals attached, or separate, or in branching non-spherical colonies of few individuals ( $\mathrm{I}$ to 30 ); or not attached, inhabiting a tube.

f. Not attached, inhabiting a tube ; individuals separate or with young (fig. 9).

Conochilus sp.

ff. Attached, separated, or in branching colonies of one to 30 individuals.

g. Corona of 3 or 4 lobes, ventral antennæe obvious, dorsal antennæe minute (fig. 8).

Melicerta.

gg. Corona of not more than two lobes.

h. Corona broad, of two lobes, with a wide dorsal gap; dorsal antennæ present; minute ventral antennæ; tube without pellets.

hh. Corona nearly circular or indistinctly two lobed.

i. Dorsal antenna very large, with two projections or hooks at its sides ; ventral antennæ small or absent.

Cephalosiphon.

ii. Dorsal antenna inconspicuous or absent; ventral antenna obvious ; dorsal gap minute.

Oecistes.

cc. Corona without setæe and with at most a minute ciliary wreath.

d. Corona with one dorsal lobe ; body long.

APSILIDE: Acyclus.

dd. Coronal cup a large membranous sack; body short and thick ; no foot, but a disk (fig. 7).

Apsilus.

bb. Not fixed when adult, and but rarely living in a tube in which case is not attached by its foot to the bottom of the tube.

c. Body bearing swimming or skipping appendages, in the form of movable spines or blades, no foot, no armor (fig. 4I).

SCIRTOPODA, PEDAlionid E, Genus Pedalion.

cc. Foot usually present.

d. Without an unyielding armor, that is, the cuticle of the animal is flexible.

ILLORICATA.

e. Foot ending in a single pointed toe, or with two projections not side by side, but one ventral and one dorsal, and corona a circle of strong cilia, mouth in the center, form of body conical; one eye.

MICROCODONID.I.

f. Foot narrow stillette form; corona heart shaped; cingulum dorsally and ventrally slightly interrupted; brain purple; always with an accessory claw at the base of the toe (fig. 12). Microdon. Compare Notommata monopus with reddish body and Albertia naidis which is eyeless.

ff. Foot shorter and broader; corona circular, without interruption ; brain not purple.

Microcodides.

ee. Foot absent, or present and with two toes, or otherwise different (If without foot, and spherical in form and with a ciliary wreath see Trochosphaera solstitialis.) 
f. No anus, intestine ending blindly; body more or less sac like.

ASPLANCHNID王.

g. Body very large; cuticle delicate; jaws incurlate; stomach without blind evaginations.

h. Foot present; viviparous.

Asplanchnopus.

hih. Foot absent (fig. I3).

Asplanchna.

gg. Body very small, cuticle firm; jaws of the forcipate type (fig. 39 ), stomach with blind sacs, which may nearly fill the body cavity.

Ascomorpha.

ff. Anus present.

g. Foot wanting; body bearing swimming or skipping appendages in the form of moveable spines, blades, or branching crustacealike limbs (except in Anarthra aptera).

THRIARTHRIDE.

h. With skipping appendages.

i. Twelve blade shaped appendages, with serrate edges, in four groups; one eye (fig. I8).

Polyarthra.

ii. With fewer appendages; two eyes.

j. Two very long spines.

Pedetes.

jj. Three long spines (fig. 16).

111. No such appendages, foot present.

Triarthra.

Anarthra.

gg. Foot present, with two toes side by side; body without swimming appendages.

h. Corona large, nearly transverse, with prominences bearing styles.

i. Form a broad, often swollen cone, of which the foot forms the apex, corona transverse, flat or strongly convex, with 4 long styles and a number of style-like prominences; at the sides of the corona two large ciliated auricles which may be retracted,

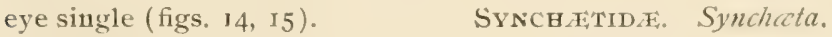

ii. Corona slightly oblique, surrounded by a wreath of cilia which is interrupted ventrally, and bearing a number ( 3 to 7 ) of large prominences crowned with styles; mouth near ventral side of corona, no ciliated auricles.

HYDATINID

j. Corona extended dorsally into a large and broad proboscis fringed with cilia and bearing near its end two red eyes.

Rhinops.

jj. With a different combination of characters.

k. Eyes two; jaws forcipate (fig. 39), foot slender, of three joints ; stomach with six long cæcal projections.

Triphylus.

$\mathrm{kk}$. A single eye or without eye.

1. Eye colorless (or wanting?) body long conical, (fig. 17).

11. Eye one, usually red.

Hydatina.

w1. Body long conical, humped dorsally, its outline with three distinct curves; corona with three style-like prominences, ciliary wreath encircling the corona and a subquadrate space at right angles to the corona on the ventral surface.

Cyrtonia. 
mm. Body quadrate, or sac-like, or strongly arched dorsally.

Notops.

hh. Corona without prominences bearing styles, consisting of an oblique (or even ventral) disk or area covered with close set cilia or with numerous interrupted ciliary curves; two lateral evertible ciliated projections (auricles) present in many species; jaws forcipate; soft flexible elongate species.

Notommatid 死.

i. Parasitic. External, Pleuratrocha; internal, Albertia and Proales.

ii. Not parasitic.

j. Body elongate, fusiform with numerous marked annulations ; head enlarged, with a decurved hood or fleshy proboscis in front ; free swimming.

jj. With other characters.

k. With one or no eyes.

1. No eyes ; indications of neck, a small hood like proboscis in front; auricles present. Pleurotrocha.

11. One eye.

m. Eye in the neck some distance from the front of the head.

n. Body with numerous prominent annulations or crenulations.

Taphrocampa.

nn. Without such annulations though divisible into a number of 'joints.

o. Species .2 to $.7 \mathrm{~mm}$. in length, brain three to five lobed.

Copeus.

oo. Smaller species; if large, their body is sac-like or without auricles.

p. Auricles present; brain usually partly opaque, not three lobed.

Notommata.

pp. Auricles absent; brain clear.

Proales.

mm. Eye frontal, placed near or at the anterior end of the body; body cylindrical.

Furcularia.

$\mathrm{kk}$. With two or three eyes.

1. With three eyes.

m. Eyes in a transverse row near posterior end of the brain.

Triophthalmus.

nm. One large eye in the neck, two smaller ones on the front.

Eosphora.

11. With two eyes.

m. Eyes frontal (fig. 19).

Diglena.

mm. Eyes in the neck.

Distemma.

dd. With a stiffened cuticle forming an armor.

LORICA'TA.

e. Foot present.

f. Foot transversely wrinkled or ringed; very retractile.

g. Foot ending in a ciliated cup; armor dorso-ventrally flattened, thin ; corona transverse, ciliary wreath two lateral semi-circles; eyes two (figs. 28, 29).

Pterodinide, Pterodina.

gg. Foot ending in one or two, usually small, toes. 
h. Armor arched dorsally, flat or slightly convex ventrally; spines or teeth usually present at anterior dorsal margin of the armor. (fig. 30 ).

BRACHIONIDA, Brachionus.

hh. Armor of different structure.

i. Arwor an irregular oblong or ellipsoidal box, marked with grooves and sometimes with vesicles closed behind, open ventrally for the protrusion of the foot; foot ending in two toes and situated on ventral side of the body. (Fig. 37).

PleEsomatid E, Plosoma.

ii. Armor compressed laterally ; covering entire body excepting for two round openings; without distinct grooves and sculpture ( fig. 38 ).

GASTROPODIDE Gastropus.

ff. Foot not transversely wrinkled nor ringed, though often jointed.

g. Armor unsymmetrical, of one piece, cylindrical, fusiform, ovate or conical, closed all around but open at each end, smooth, rather thin; one eye; foot very short, with one or more very slender, stiff, bristle-like toes.

RATTULIDA.

1. The two toes equal or the shorter more than one-third the length of the longer (fig. 20).

Diurella.

hh. A single toe usually with an inconspicuous shorter one not more than a third the length of the longer (fig. 21). Rattulus,

gg. When viewed dorsally the armor is symmetrical.

h. Armor cleft down the middle of the back by a fissure whose sides are united by membrane; open at both ends for the projection of the head and foot; toes blade shaped.

i. Armor only slightly developed, covering only the dorsal half of the body ; median fissure not strongly marked; one eye.

DIASCHIZIDA, Diaschiza.

ii. Armor well developed, an oblong box enclosing the body, open at both ends and distinctly cleft down the back. SALPINID 2 .

j. Armor with neither anterior nor posterior spines; eye usually wanting.

Diplax.

jj. Armor with spines either anteriorly or posteriorly or both ; eye present ( fig. 23, 24).

Mytilina (Salpina).

hh. Armor not dorsally cleft.

i. Armor only laterally cleft, of two plates, the ventral one nearly flat ; foot proper short and inconspicuous, of one or two joints ; body ending in one or two large rod shaped toes, one eye.

CATHYPRIADE:

j. 'Toes two.

k. Armor subcircular or broadly ovoid with wide and deep lateral furrow ; mainly larger species. Cathypria.

kk. Armor longer, usually a long ellipse, open in front; lateral furrow not pronounced.

jj. One rod shaped toe (fig. 26).

Distyla.

ii. Armor of a different structure or foot with three segments.

j. Armor of a single piece, like a coat covering only the anterior half of the dorsal surface of the body or less; foot long, jointed, with two minute toes, (Cochleare) or head sur- 
mounted by an arched chitinous shield, appearing in side view like a hood, armor either arched and compressed, open behind and in front (Colurella, fig. 27), or of equal height and width or depressed, not open ventrally (Metopia).

COLURELIIDE.

jj. With other characteristics.

$\mathrm{k}$. Armor of two dissimilar plates, one dorsal and one ventral, the former larger and arched (except in one species), the latter flat or slightly convex; large transparent rotifers with a single eye ; foot jointed, the two toes large, usually blade shaped. (fig, 25).

EUCHLANIDA, Euchlanis.

$\mathrm{kk}$. Armor of a different structure.

1. Armor with two or four spines on posterior margin; head without shield; either anterior margin of armor with two spines (Noteus quadricornis) or with ten spines (N. militaris) or dorsum with one (B. gleasonii); foot distinctly jointed ending in one or two toes. BRACHIONIDA:

m. Armor (not including length of spines) as long as broad or but little longer, smooth, granulate, or with polygonal areas.

n. Foot simple, conical, not jointed, at most transversely wrinkled (fig. 30).

Brachionus.

nu. Foot distinctly three jointed (fig. 32).

Noteus.

mm. Armor (not including the spines) much longer than broad, always smooth.

Schizocerca.

11. Foot and toes usually very long, or if not, dorsum of armor with long spines or head with distinct shield.

DINOCHARID开。

m. Armor flattened and bearing one or more spines on its dorsal surface, eyes one or two; if not spined then two eyed and with broad, nearly circular projecting plate over head, halo-like, and armor cylindrical or pyriform.

n. A single median eye.

Polychatus.

nn. Two eyes.

Stephanops.

mm. Armor not bearing spines on dorsal surface, entire (not cleft dorsally and ventrally) vase shaped or compressed, eye one; foot very long.

n. Head retractile, with a chitinous cap; foot bearing two spines dorsally; foot and toes together nearly or quite twice as long as the body ; armor facetted, and surface roughened (fig. 22).

Dinocharis.

nn. Head with thin chitinous covering; armor vase shaped, thin, smooth, and transparent.

Scaridium.

ee. Foot absent.

f. Armor oval compressed, without teeth or spines; head with long finger-like processes (fig. 40).

ANAPODIDA, Anapus.

ff. Armor ustally with teeth or spines; head without finger-like processes.

ANUREIDE.

g. Anterior margin of armor with six spines. 
1. Dorsum of armor marked off into polygonal areas. (fig. 35,36 ).

Anuraea.

hh. Dorsum of armor with longitudinal furrows or striations (fig. $33,34)$,

Notholca.

gg. Anterior margin of armor without spines.

Anurcopsis.

\section{CRUSTACEA.*}

The following table includes the genera of only the free swimming, fresh water Entomostraca found in eastern United States. An immature stage, known as Vauplius is shown in fig. 3 .

a. Without a shell-like covering of the body ; with four or five two-branched swimming feet on the thorax, abdomen without appendages.

COPEPODA.

b. Cephalothorax distinctly separated from abdomen, the latter small.

c. First antennæ long, about as long as the body, 23-25 segmented; in the male one is modified into a grasping organ ; fifth feet not rudimentary.

CENTROPAGIDA:

d. Endopodites of swimming feet composed of three segments.

e. Antennæe of 23 or 24 segments.

ee. Antennæ of 25 segments (fig. I7)
Osphranticum labronectum.

Limnocalanus macrurus.

dd. Endopodite of first swimming feet of one or two segments.

e. Endopodite of first, second, third, and fourth swimming feet of one segment.

Epischura lacustris.

ee. Endopodite of first swimming feet of two segments; of third and fourth feet of three segments (fig. I6).

Diaptomus.

cc. Antennze shorter than cephalothorax, with not more than $17 \mathrm{seg}-$ ments; female with two egg sacks (fig. 20).

CYCLOPID A: Cyclops.

bb. Cephalothorax and abdomen not sharply differentiated; antennze short, at most eight segmented.

With 8-segmented antennæ (fig. 19)

HARPACTICIDAT.

Canthocamptus.

aa. Usually with a shell like covering which may or may not entirely cover the body ; if without shell the paired eyes are pedunculate.

b. Trunk limbs leaflike in form; mandible without palp.

c. With ten or more pairs of trunk limbs.

PHYLLOPODA.

d. Without shell; paired eyes pedunculate. The fairy shrimps, etc.

ANOSTRACA.

e. Clasping antennæ of male biarticulate. Frontal appendage present.

CHIROCEPHALIII:

f. Frontal appendage of male rather short ; terminal segment of copulatory organ smooth (fig. 2I).

Eubranchipus.

ff. Frontal appendage of male long and vertical ; terminal segment of copulatory organ spiny.

Branchinella.

ee. Clasping antennæe of male triarticulate.

STREPTOCEPHALIDE. Streplocephalus.

* Adapted from Embody, Herrick, Van Douwe, et al. 


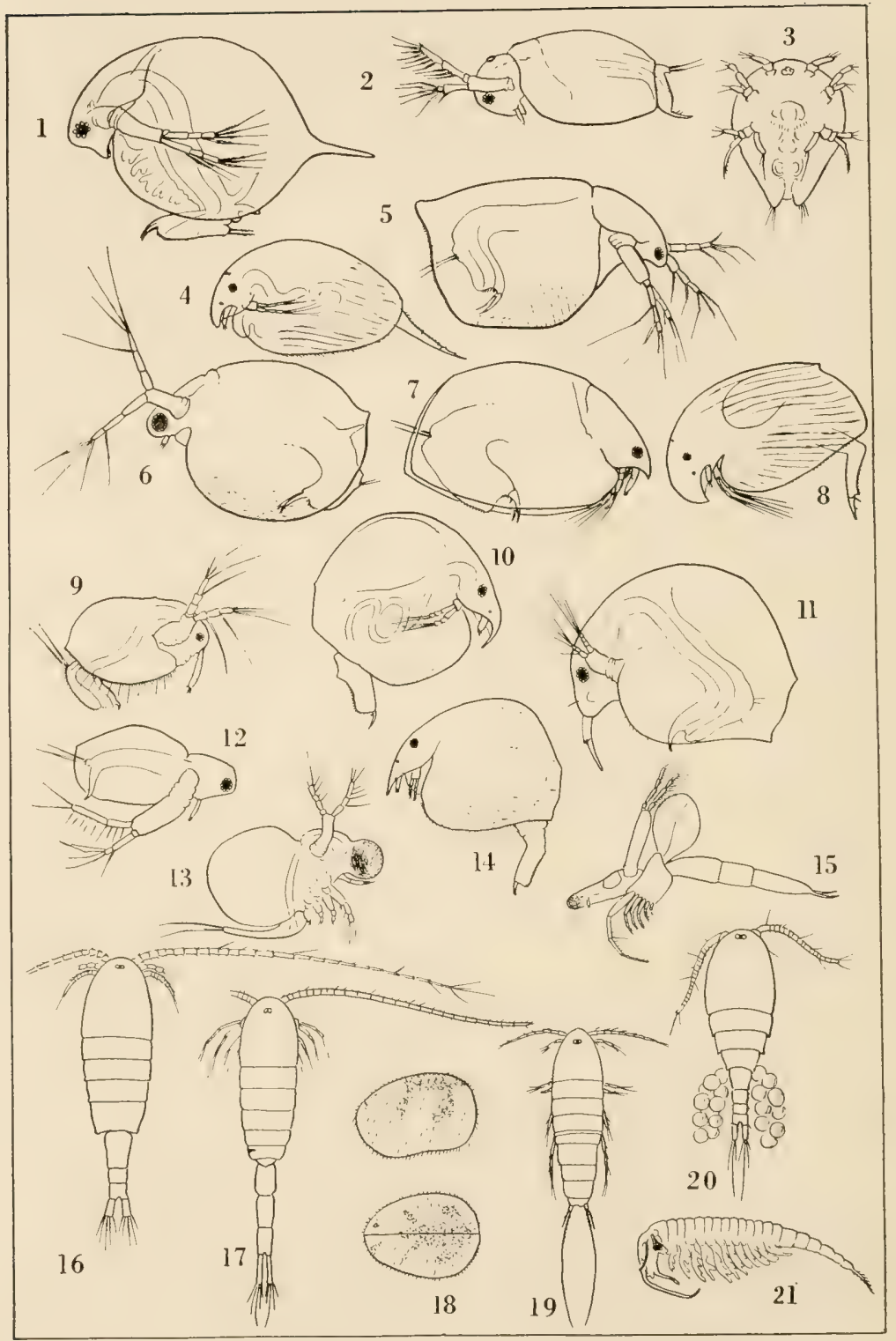

IX-CRUSTACEA. I, Daphnia. 2, Sida. 3, Nauplius. 4, Camptocerus. 5, Simocephalus. 6, Ceriodaphnia. 7, Eurycerus. 8, Acroperus. 9, Macrothrix. Io, Chydorus. II, Bosmina. I2, Diaphanosoma. I3, Polyphemus. I4, Alonella. 5, Leptodora. I6, Diaptomus. I7, Limnocalanus. I8, Cypridopsis. I9, Canthocamptus. 20, Cyclops. 2I, Eubranchipus. 
dd. With shell; paired eyes sessile.

e. Shell resembling that of a small clam.

CONCHOSTRACA.

f. Shell spheroidal without lines of growth. LIMNETIDE. Limnetis.

ff. Shell with concentric lines of growth.

g. Shell with 4 to 5 lines of growth.

LIMNADIID互.

Eulimnadia.

gg. Shell with I 8 to 22 lines of growth.

h. Pediculated dorsal organ on front of head; $18-22$ pairs of limbs.

Limnadia.

hh. No dorsal organ present; 24 to 28 pairs of limbs.

Estheria.

ee. Shell not clam like.

NO'TOSTRACA.

cc. With $\&$ to 6 trunk limbs ; shell bivalved, generally covering body but leaving head free.

CLADOCERA.

d. Shell restricted to the brood chamber; feet flattened and jointed.

GYMNOMERA.

Polyphemus pediculus (fig. 13) and Leplodora kindti (fig. 15).

dd. Shell covering the body; feet not distinctly jointed.

CALYPTOMIRA.

e. Six pairs of feet; foliaceous.

CTENOPODA.

f. Swimming antenna of female two branched, the dorsal with many lateral and terminal setæe.

SIDIDAE:

g. Dorsal ramus 3-jointed, ventral ramus 2-jointed; beak present (fig. 2).

Sida.

gg. Dorsal ramus 2-jointed, ventral ramus 3 -jointed.

h. Dorsal ramus with interior process or expansion on basal joint.

Latona.

hh. Dorsal ramus without process.

i. Posterior margin of shell valves with several long setæ.

j. Eye dorsal far from insertion of antennule.

jj. Eye ventral or in middle of head.

Latonopsis.

ii. Posterior margin of shell valves without setæe. (fig. I2).

Diaphanosoma.

ff. Animal enclosed in a large globular, transparent, gelatinous case open ventrally and forming two valves. Antenna of female with single ramus.

HoLopenidaE. Holopedium.

ee. Five or six pair of trunk limbs, first two pairs more or less prehensile.

ANOMOPODA:

f. Second antennæe with superior branch 4-segmented; inferior branch 3-segmented.

g. With five pairs of feet; first antennæ small, if rarely large, (as in Moina) then not inserted at anterior end of head; intestine with 2 hepatic cæca.

DAPHNIDAE.

h. Head of female with a beak.

i. Head keeled above; no transverse suture on neck; shell with polygonal marks and with posterior spine (fig. I). Daphne.

ii. Head not keeled; neck suture present.

$\mathrm{j}$. Spine on shell produced in a straight line with the ventral margin ; shell with indistinct net like markings. Scapholeberis.

jj. Spine absent or very short and blunt; markings of transverse lines (fig. 5).

Simocephalus. 
hh. Head withont a beak.

i. First antenna of female very short, head small and depressed (fig. 6).

Ceriodaphnia.

ii. First antenna large, head high. Moina.

gg. First antenna long; often with 6 pairs of feet; usually no hepatic creca.

h. First antennz large and fixed; six pairs of feet (fig. II).

BOSMINID五. Bosmina.

hh. First antennæ long and freely movable. MACROTHRICIDA.

i. Intestine convolute.

j. Valves with spine at upper posterior angle.

jj. Spine absent.

$\mathrm{k}$. Convolutions of intestine in middle of body.

1. Dorsal margin of shell with conspicuous short backward pointing tooth about the middle.

Ophryoxus.

11. No dorsal tooth,

Drepanothrix.

$\mathrm{kk}$. Convolutions of intestine in hind part of body.

1. Posterior margin of shell truncated. A slight cervical sinus present.

Acantholeberis.

11. Posterior margin rounded with slightly pointed protuberance in middle.

Streblocerus.

ii. Intestine simple.

j. Upper posterior margin of shell truncated diagonally; general form oval-triangular, the head constituting the apex. Ventral and posterior edges of valves enormousiy dilated and rounded into each other, these having long close set setæ usually branched and fringed. Ilyocryptus.

jj. General form ovate, upper posterior margin of shell rounded, not truncated. Setæ on ventral margin of shell only.

$\mathrm{k}$. Setæ long, movable, spine like and projecting in several directions. (fig. 9.) Macrothrix.

kk: Setæ short and close set; mid-posterior extremity forming apex of roughly heart-shaped shell.

Lathonura.

ff. Second antenna with both branches three segmented.

CHYDORID E:

g. Anus at extremity of post abdomen; two hepatic cœeca (fig. 7).

Eurycerus lamellatus.

gg. Anus on dorsal side of post abdomen; no hepatic cœeca.

h. Head and back with high keel; post abdomen very long and slender; with marginal and lateral teeth. (fig. 4).

Camptocerus.

hh. Not with all the above characters.

i. Hind margin of shell not much less than the greatest depth (height).

j. Body compressed; claw on the concave side with one or two teeth in the middle.

k. Shell with crest, Kurzia, and Acroperus (fig, 8).

kk. No crest; post abdomen with marginal and lateral teeth.

Alonopsis, Euryalona. 
jj. Body not much compressed; claw without tooth or with basal tooth only.

k. Beak not produced much beyond first antennæe. Oxyurella, Leydigia, Alona, Graptoleberis.

kk. Beak much longer than the first antennx.

Alonella in part, and Rhynchotalona.

ii. Hind margin of shell much less than greatest depth.

j. Body noticeably longer than wide.

Pleuropus, Alonella in part, Dunheredia.

jj. Body spherical or nearly so.

k. Post abdomen short with prominent pre-anal angle; shell without conspicuous projection on antero-ventral angle (fig. IO).

Chydoms.

kk. Post abdomen large, pre-anal angle not conspicuous (fig. I4). Alonella.

bb. Trunk limbs not leaf like; mandible with palpus; body not distinctly segmented; with caudal furca ; antennæ large, used for locomotion : bivalve shell enclosing entire body.

OSTRACODA.

c. Last pair of trunk limbs bent backwards within the shell and not used for locomotion.

CYPRIDID F: About I2 eastern genera. Cypridopsis vidua is most common. It has a broad shell marked dorsally and laterally with 3 prominent dark bands. (fig. I8).

cc. Last pair of trunk limbs directed downwards and used for locomotion.

CYTHERIDA:

The genus Limnicythere is the only free swimming freshwater form in our region. 




SMITHSONIAN INSTTUUTION LIBAARIES

उ9088 011244787 